\title{
The Role of Digital Consumer Protection in Mediating the Effect of Mobile Money usage towards Financial Inclusion: an Evidence from Buleleng, Indonesia
}

\author{
Luh Regita Eka Pratiwi $^{\# 1}$, Astrie Krisnawati ${ }^{* 2}$ \\ ${ }^{\text {"}}$ Faculty of Economics and Business, Telkom University \\ Jl. Gegerkalong Hilir No. 47, Bandung 40152
}

\begin{abstract}
The current utilization of digital services especially in finance sector among the productive age communities is increasing. Mobile money utilization and the implementation of a digitalization system in the financial sector are expected to increase financial inclusion. By increasing financial inclusion, the poverty rate is also expected to be reduced. Buleleng Regency is one of regency in Bali Province, Indonesia which has a high poverty rate. It is necessary to increase financial inclusion through mobile money usage. However, it is also necessary to increase consumer protection to support this digitalization. This research aims to determine the effect of mobile money usage on financial inclusion with digital consumer protection as a mediator in productive age communities in Buleleng Regency, Bali, Indonesia. The population of this research consists of 439,400 people from productive age group in Buleleng Regency, Bali, Indonesia. This research used a non-probability sampling technique with the total of 477 samples. This research applies the Sobel test, Baron and Kenny's mediation analysis, and the PROCESS method by Hayes. The results of this study show that digital consumer protection partially mediates the effect of the mobile money usage on financial inclusion in Buleleng Regency, Bali, Indonesia. Based on the results of this study, it is suggested to regulators and related agencies in Indonesia to show more attention about the safety factors of mobile money users by strengthening consumer protection in terms of both regulation and the system reliability. Furthermore, it is also necessary to develop education programs on how to manage finance properly by using mobile money in order to improve people's welfare.
\end{abstract}

Keywords - digital consumer protection, mobile money usage, financial inclusion, poverty

\section{INTRODUCTION}

The current industrial revolution 4.0 era rapidly increases information technology development and internet development. Currently, Indonesian internet users reach 175.4 million, with a $64 \%$ penetration, and $98 \%$ of the total internet users are recorded in using mobile internet ${ }^{[34]}$. Concerning this matter, digitalization takes place in financial transaction processes, e.g., the emergence of various financial technology platforms, mobile money usage such as e-money, mobile payment, and others. Mobile money is also termed as e-money ${ }^{[24]}$. Mobile money is a mobile e-money accessible through a smartphone. Several telecommunication providers (Telkomsel, Indosat, and XL) provide mobile money services for their users to send and receive money through their networks ${ }^{[11]}$. E-money transactions in the Indonesian retail market jacked up by $173 \%$ in January $2020^{[19]}$. The number of electronic money (e-money) instrument utilization increased during the pandemic of Covid-19 era and the establishment of Large-Scale Social Restrictions. In April 2020, the number of electronic money users reached 412.1 million, increasing from the previous month by 330.4 million $^{[22]}$. During the pandemic of Covid-19, digital payment has helped many individuals and MSMEs in transacting. Digital payments also related to the development of the economy and the retail sector ${ }^{[38]}$.

Mobile money takes a role in increasing financial inclusion as a payment and money delivery instrument in developing countries. It can serve low-income communities without bank accounts. It also reaches people with limited access to formal financial services in remote areas ${ }^{[17]}$. Financial inclusion also acts as a development goal booster in the Sustainable Development Goals (SDGs) to help poverty alleviation ${ }^{[43]}$. Based on the Financial Literacy and Financial Inclusion National Survey conducted by the Financial Service Authority the financial literacy and financial inclusion rate in Indonesia was $38.03 \%$ and $76.19 \%$, respectively ${ }^{[32]}$. The financial inclusion rate of $76.19 \%$ is lower than other SEA countries, e.g., Singapore, Malaysia, and Thailand. 
DOI: $\underline{10.51386 / 25815946 / \mathrm{ijsms}-\mathrm{v} 4 \mathrm{i} 5 \mathrm{p} 116}$

Volume: 4 Issue: 5

September to October 2021

https://www.ijsmsjournal.org

Therefore, financial inclusion improvement measures are required by utilizing digital financial services and digital consumer protection reinforcement ${ }^{[10]}$.

Based on the Financial Service Authority's survey in 2019, the Bali Province was one of the provinces with a higher financial inclusion index than the average national financial inclusion index, amounting to 92.19\%. However, its financial inclusion rate does not reflect the real number since the survey was performed only in several regencies or cities ${ }^{[32]}$. Although the Bali Province's financial inclusion rate is relatively high, problems remain to exist regarding the limited access for communities to financial services, e.g., banks, due to obstacles such as socioeconomic, institutional, low-income, complicated banking requirement and operational, high banking administration fee, low banking and financial education, and distant location from the residence to the bank ${ }^{[42]}$. These phenomena cause imbalance and discrepancy of formal financial access between the North and South Bali since financial service access development is more concentrated in South Bali ${ }^{[25]}$. One of the fascinating regencies to be examined is the Buleleng Regency, located in North Bali.

The Statistics Central Bureau's data stated the low-income population percentage at Buleleng in 2019 was $5.19 \%$, increasing to $5.32 \%$ in 2020 . It places Buleleng as the regency with the second-highest low-income population percentage compared to other regencies in the Bali Province ${ }^{[3]}$. Buleleng Regency still has a high poverty rate, uneven education levels, and unstable economic growth ${ }^{[35]}$. Based on the phenomena and problems at the Buleleng Regency, financial inclusion improvement is required to overcome the discrepancy problem. The potential lies in the digitalization utilization in the financial sector. In 2019, the percentage of Buleleng Regency's population over five years using cellphones was $78.03 \%$, while the population over five years accessing the internet was $38.66 \%{ }^{[4]}$. Buleleng Regency is the most populated region in Bali. Thus, these excessive human resources should be developed to increase economic growth and reduce the region's poverty rate by employing the available people in the productive age group (15-64 years). Following the developing utilization of mobile money and financial technologies, plausible risks emerge. These risks are associated with data theft, transaction fraud, system error, and more. These crime attempts also include money mule activity (transferring money from criminal actions from one bank to another), identity theft, and identity forgery, which are estimated to grow in Indonesia ${ }^{[37]}$. Hence, it can be concluded that increased mobile money usage will be followed by increased risk potentials. A robust digital consumer protection framework is essential to provide a sense of safety and trust for the consumers in using various mobile money services. This digital consumer protection is crucial since it affects consumer trust in continuing their use of the mobile money service ${ }^{[6]}$.

In the past decade, digital financial services, including mobile money, have recorded rapid growth contributing to the financial inclusion expansion ${ }^{[1]}$. Mobile money gave a significant impact on household ability in Kenya to share risks. It is caused by the reduced transaction fee ${ }^{[21]}$. Mobile money usage encourages financial service access and uses, particularly in rural communities ${ }^{[27]}$. Mobile money usage has an indirect effect on the financial inclusion of rural communities in Uganda ${ }^{[7]}$. The trust factor improves the adoption of mobile money and its usage to improve the MSME financial inclusion reach in developing countries ${ }^{[8]}$. Mobile money usage and adoption have impacts (direct and indirect) on financial inclusion, while financial inclusion is influenced by mobile money usage and adoption and digital consumer protection ${ }^{[6]}$. It is concluded that digital consumer protection can mediate the effect of mobile money usage and adoption on the financial inclusion of North Uganda MSMEs ${ }^{[6]}$. The existence of a robust digital consumer protection program that applies to financial services is vital in developing trust and faith from consumers to reduce the doubt upon digital financial systems regarding data safety and losses from wrong transactions ${ }^{[26]}$. Based on the phenomenon explanation, the current study aimed to discover the effect of mobile money usage on financial inclusion, the effect of mobile money usage on digital consumer protection, the effect of digital consumer protection on financial inclusion, and the role of digital consumer protection in mediating the effect of mobile money usage on financial inclusion of the productive age group at the Buleleng Regency, Indonesia.

\section{LITERATURE REVIEW}

This research adopts financial behavior theory which can be explained as human behavior related to financial management activities ${ }^{[49]}$. Financial behavior is related to how a person manages his finances. Furthermore, according to Xiao (2008) financial behavior in general is also related to cash flow management, credit, and saving or investment behavior ${ }^{[49]}$. Financial behavior is also defined as how well households or individuals manage financial resources which include budget planning, savings, insurance, and investment ${ }^{[16]}$. 
DOI: $\underline{10.51386 / 25815946 / \mathrm{ijsms}-\mathrm{v} 4 \mathrm{i} 5 \mathrm{p} 116}$

Volume: 4 Issue: 5

September to October 2021

https://www.ijsmsjournal.org

Financial behavior is a person's behavior in the financial sphere as well as an important factor in achieving financial satisfaction ${ }^{[23]}$. This theory of financial behavior then becomes a reference for the development of other theories related to this research.

\section{A. Mobile Money Usage}

Mobile money can be defined as a mobile-based money delivery service using an information and communication technology device and non-banking network to offer and expand financials services to consumers whom formal and traditional financial service providers fail to reach ${ }^{[44]}$. Mobile money enables individuals to have financial transactions using a cellphone technology ${ }^{[20]}$. Mobile money usage is measured using Venkatesh et al., (2002) items such as intention to use and user satisfaction ${ }^{[45]}$.

\section{B. Financial Inclusion}

Based on the Indonesia Financial Service Authority Regulation, financial inclusion is the access available for communities to use financial products or financial services following their need and ability through financial service institutions to achieve prosperity ${ }^{[33]}$. Financial inclusion goals are:

a. Improved access for the community to the formal financial sector, including financial institutions, products, and services

b. Improved availability of formal financial products and services in financial institutions

c. Improved financial product and service utilization following communal ability and need

d. Improved financial product and service quality following communal ability and need

Financial inclusion is defined as the condition where all adults in the productive age group have effective access to various financial products and financial services, e.g., saving, loan, insurance, and payment system, from formal financial service providers ${ }^{[13]}$. Financial inclusion can be defined as the process of promoting access to financial products and financial services that are affordable, timely, and sufficient. It is regulated through an innovative approach implementation, adjusted to other aspects, such as financial education and awareness to promote financial welfare and economic and social inclusion ${ }^{[2] .}$. Financial inclusion dimensions comprise access, quality, usage, and welfare ${ }^{[7]}$.

\section{Digital Consumer Protection}

The Restricted Access or Limited Control states the importance of strict control implementation in determining a privacy context or zone to limit other people to one's personal information ${ }^{[28][29]}$. RALC implementation helps to shape a comprehensive online privacy policy to overcome various privacy problems regarding digital transactions ${ }^{[6]}$. Consumer protection is a crucial element of an inclusive financial system, ensuring that current formal financial service users obtain transparent and fair treatment. Hence, it fosters trust in formal financial system and financial providers among potential consumers ${ }^{[15]}$. Furthermore, digital consumer protection in the form of comprehensive risk knowledge, awareness of fraud and prevention offered by providers to remind the consumers, officers, and agents concerning the risk trend and preventive actions highly improves the mobile money service absorbance ${ }^{[15]}$. The World Bank asserts that protection for the consumers in mobile money platforms should guarantee that consumers have sufficient information in making decisions acquired by access availability to the help mechanism to solve disputes to prevent unfair practices by mobile money service providers and irresponsible parties ${ }^{[46][47][4]}$.

\section{METHODOLOGY}

\section{A. Research Model}

This study employed a study method that involves several variables. The first variable is mobile money usage. Then digital consumer protection. The last is financial inclusion. Under the precedent theory and study development, the researchers conducted analyses comprising:

1) The analysis of mobile money usage effect on financial inclusion

2) The analysis of mobile money usage effect on digital consumer protection

3) The analysis of digital consumer protection effect on financial inclusion

4) The analysis about mobile money usage effect on financial inclusion with digital consumer protection as the mediator

A suitable framework and hypothesis were developed based on the theory and literature study development as mentioned above. The developed framework is illustrated in figure 1 as follows: 


\section{DOI: $\underline{10.51386 / 25815946 / \mathrm{ijsms}-\mathrm{v} 4 \mathrm{i} 5 \mathrm{p} 116}$}

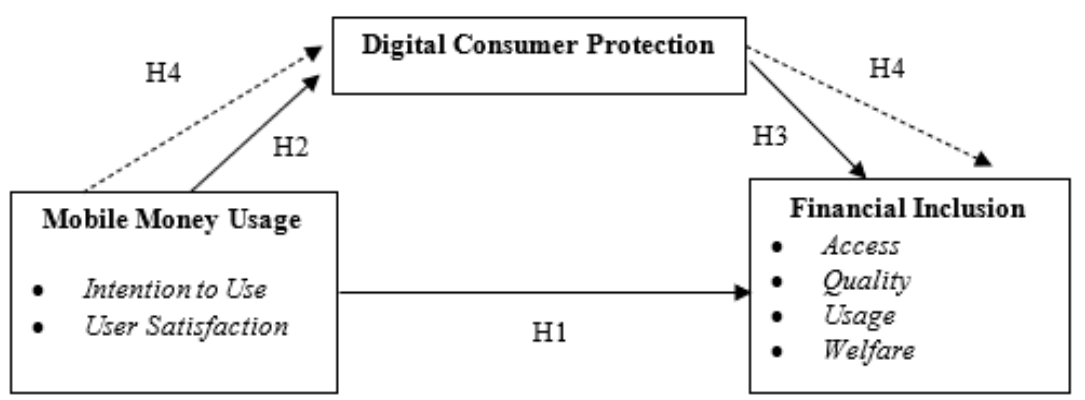

Fig 1. Research Framework on the Relationship between Variables

Based on the figure 1 theoretical background and framework, the proposed study hypotheses are:

H1: Mobile money usage significantly affects financial inclusion.

$\mathrm{H} 2$ : Mobile money usage significantly affects digital consumer protection.

H3: Digital consumer protection significantly affects financial inclusion.

H4: Digital consumer protection mediates the effect of mobile money usage on financial inclusion.

\section{B. Population and Sample}

The population of this study was the productive age group in the Buleleng Regency, ranging from 1564 years, amounting to 439,400 people. The non-probability sampling technique using the Slovin formula:

$$
n=\frac{N}{1+(N e 2)}
$$

where:

$\mathrm{n}=$ sample size

$\mathrm{N}=$ population size

$e=5 \%$ (slack constant of inaccuracy due to tolerable sample decision errors)

So, the sample size for this study is:

$$
\begin{aligned}
& n=\frac{439,400}{1+439,400(0.05)^{2}} \\
& n=\frac{439,400}{1099.5} \\
& n=399.64
\end{aligned}
$$

The calculation using the Slovin formula obtained 399.64 or minimum sample size is 400 respondents. The study acquired 477 respondents of people in the productive age group at Buleleng Regency, Bali, as the study samples.

\section{Data Collection Technique}

In this study, the data used were primary data obtained from questionnaire distribution to the productive age group in the Buleleng Regency, Bali. Question items in the study questionnaire were created by referring to predecessor studies conducted by Bongomin and Ntayi (2020), Bongomin et al. (2018), and Bongomin et al. (2016) ${ }^{[6][7][9]}$. The current study employed the Likert scale to measure respondent answers categorized into five alternatives of answer level. The Likert scale is used to explain how strongly a subject agrees or disagrees with the statements classified into five answer points from strongly agree to strongly disagree $^{[39]}$. The researchers also utilized secondary data sources from the Statistics Central Bureau to acquire information concerning the population size, economic condition, and citizenship. 
DOI: $\underline{10.51386 / 25815946 / \mathrm{ijsms}-\mathrm{v} 4 \mathrm{i} 5 \mathrm{p} 116}$

Volume: 4 Issue: 5

September to October 2021

https://www.ijsmsjournal.org

\section{Analysis Technique}

The data analysis methods employed in the current study were descriptive analysis, pearson correlation analysis, classic assumption test, mediation analyzes using the theory of Baron and Kenny, data processing using regression and PROCESS in SPSS 25, and Sobel Test.

The data analysis used in this study was descriptive analysis where it illustrates various data characteristics from a sample ${ }^{[41]}$. Descriptive analysis is performed using the following formula.

Percentage $=$ cumulative value of the item $\times 100 \%$

frequency value

The score interpretation criteria consider the continuum line as follows:

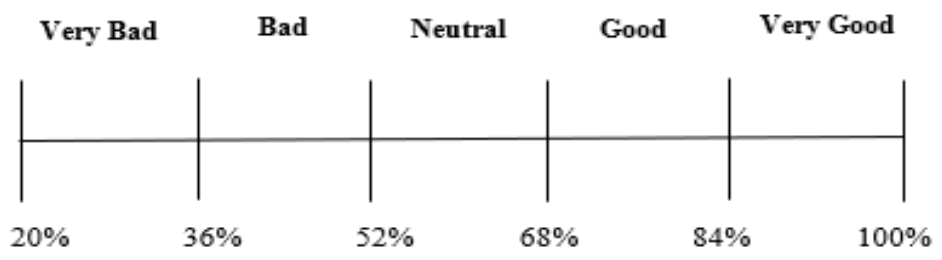

Fig 2. Score Interpretation using Continuum Line

Source: data processed

The study employed Pearson correlation to measure the relationship between two variables. Pearson correlation symbolized by $\mathrm{r}$ has the following formula:

$$
\mathrm{r}=\frac{\Sigma X Y}{\sqrt{\left(\Sigma \mathrm{x}^{2}\right)\left(\Sigma Y^{2}\right)}}
$$

Relationship strength interpretation or correlation to facilitate finding analysis is as follows:

Table 1. Correlation Level

\begin{tabular}{lll}
\hline & Coefficient Interval & Correlation Level \\
\hline $\mathbf{1}$ & 0 & No Correlation \\
\hline $\mathbf{2}$ & $>0-0.199$ & Very Weak Correlation \\
\hline $\mathbf{3}$ & $>0.2-0.399$ & Low Correlation \\
\hline $\mathbf{4}$ & $>0.4-0.599$ & Medium Correlation \\
\hline $\mathbf{5}$ & $>0.6-0.799$ & Strong Correlation \\
\hline $\mathbf{6}$ & $>0.8-0.999$ & Very Strong Correlation \\
\hline $\mathbf{7}$ & 1 & Perfect Correlation \\
\hline Source: Neolaka (2014) & Correlation Level
\end{tabular}

The classical assumption test used in this study were normality test, multicollinearity test, and heteroscedasticity test. Normality was carried out to test whether variables in the study, such as independent and dependent variables, are normally distributing ${ }^{[41]}$. The applicable statistic test to test the residual normality is a non-parametric statistical test of Kolmogorov-Smirnov, where if the Asymp sig > significance value (0.05), the data is declared normally distributed ${ }^{[18]}$. The multicollinearity test aims to test whether a correlation is discovered between independent variables in the regression model ${ }^{[41]}$. In determining multicollinearity, one can observe the tolerance value or variance inflation factor (VIF). The tolerance value limit is $>0.1$ or VIF $<10$. It indicates zero multicollinearity. Heteroscedasticity is utilized to discover variable similarity from residue from each observation in the model ${ }^{[18]}$. The heteroscedasticity test was performed by the glejser test where heteroscedasticity indication is present if independent variables significantly and statistically affect dependent variables ( $\mathrm{sig}<0.05)$. 
DOI: $\underline{10.51386 / 25815946 / \mathrm{ijsms}-\mathrm{v} 4 \mathrm{i} 5 \mathrm{p} 116}$

\section{E. Mediation Analysis}

A study model without a mediating variable shows direct effects of the independent variable on the dependent variable, while a study model with a mediating variable shows indirect effects of the independent variable on the dependent variable via the mediating or intervening variable ${ }^{[36]}$. In examining the mediating variable function, the researcher should estimate three regressions ${ }^{[5]}$. The modeling estimation consists of:

1) The first model regresses the mediating variable on the independent variable (a);

2) The second model regresses the dependent variable on the independent variable (c);

3) The third model regresses the dependent variable on the independent variable (c') and the mediating variable (b).

This Baron and Kenny's mediation analysis method development is then updated using the PROCESS method. A statistical test to observe mediation effects uses the Sobel test and bootstrapping (PROCESS) method. The Sobel test is used to discover the impact strength of independent variables on dependent variables indirectly via mediating variables. Before performing the Sobel test, a standard error should be discovered using the following formula:

$$
\mathrm{Sab}=\sqrt{b^{2} s_{a}^{2}+a^{2} s_{b}^{2}+S_{a}^{2} s b^{2}}
$$

where:

$\mathrm{a}=$ variabel independent $\mathrm{b}=$ variabel dependen

$\mathrm{sa}=$ Standard error $\mathrm{a} \quad \mathrm{sb}=$ standar error $\mathrm{b}$

The Sobel $\mathrm{Z}$ test is conducted using the following formula

$$
Z=\frac{a b}{S_{a b}}
$$

The rule of $\mathrm{Z}$ value calculation is that the Sobel $\mathrm{Z}$ score is significant if $\mathrm{Z}>$ effectiveness critical point of the mediating effect, i.e., 1.96 (significance value 5\%), and the hypothesis test will show a significant result if $p$ value $<$ significance value ${ }^{[40]}$.

\section{RESULT AND DISCUSSION}

Respondents in this study were people in the productive age group in the Buleleng Regency, Bali. Data collection in this study was conducted by distributing online and offline questionnaires, acquiring 477 respondents. A descriptive analysis was performed to illustrate the score from each variable, and each variable categorization is displayed in the Table 2:

Table 2. Result of Variables Score Interpretation for Descriptive Analysis

\begin{tabular}{|l|l|l|}
\hline \multicolumn{1}{|c|}{ Variable } & Score (\%) & Category \\
\hline Mobile Money Usage & $84.07 \%$ & Very Good \\
\hline Digital Consumer Protection & $84.34 \%$ & Very Good \\
\hline Financial Inclusion & $85.86 \%$ & Very Good \\
\hline
\end{tabular}

Source: Primary Data Processed

According to Table 2, all variables are included in the very good category. It indicates that responses from people in the productive age in the Buleleng Regency on all the variables are good and potential to be improved in achieving prosperity and reducing poverty.

Then, the Pearson correlation analysis revealed a correlation between variables, and hence, the study has fulfilled the requirements to measure a mediator since the independent variable is assumed to cause a mediator. Therefore, both variables should correlate. The Pearson correlation results are displayed in the Table 3 . 
DOI: $\underline{10.51386 / 25815946 / \mathrm{ijsms}-\mathrm{v} 4 \mathrm{i} 5 \mathrm{p} 116}$

Volume: 4 Issue: 5

September to October 2021

https://www.ijsmsjournal.org

Table 3. Result of Pearson Correlation

\begin{tabular}{|c|c|c|c|c|}
\hline \multicolumn{5}{|c|}{ Correlations } \\
\hline & & $\begin{array}{l}\text { Mobile_Money_ } \\
\text { Usage }\end{array}$ & $\begin{array}{l}\text { Digital_Consume } \\
\text { r_Protection }\end{array}$ & $\begin{array}{l}\text { Financial_Inclusi } \\
\text { on }\end{array}$ \\
\hline \multirow[t]{3}{*}{ Mobile_Money_Usage } & Pearson Correlation & 1 & $.773^{* *}$ & $.696^{* *}$ \\
\hline & Sig. (2-tailed) & & .000 & .000 \\
\hline & $\mathrm{N}$ & 477 & 477 & 477 \\
\hline \multirow[t]{3}{*}{ Digital_Consumer_Protection } & Pearson Correlation & $.773^{* *}$ & 1 & $.706^{* *}$ \\
\hline & Sig. (2-tailed) & .000 & & .000 \\
\hline & $\mathrm{N}$ & 477 & 477 & 477 \\
\hline \multirow[t]{3}{*}{ Financial_Inclusion } & Pearson Correlation & $.696^{* *}$ & $.706^{* *}$ & 1 \\
\hline & Sig. (2-tailed) & .000 & .000 & \\
\hline & $\mathrm{N}$ & 477 & 477 & 477 \\
\hline
\end{tabular}

Source: Primary Data Processed using SPSS25

According to Table 3, the $\mathrm{r}$ correlation value between mobile money usage and digital consumer protection was 0.773 , the significance value of $0.000<0.05$. Indicating that mobile money usage had significant and positive correlation with digital consumer protection with a strong correlation category. It shows that increased mobile money usage will increase digital consumer protection. The $\mathrm{r}$ correlation value between mobile money usage and financial inclusion was 0.696 , the significance value of $0.000<0.05$. Indicating that mobile money usage had a significant and positive correlation with financial inclusion with a strong correlation category. It shows that increased mobile money usage will increase financial inclusion. The $\mathrm{r}$ correlation value between digital consumer protection and financial inclusion was 0.706 , the significance value of $0.000<0.05$. Indicating that digital consumer protection had a significant and positive correlation with financial inclusion with a strong correlation category. It shows that increased digital consumer protection will increase financial inclusion.

Based on the normality, multicollinearity, and heteroscedasticity tests, the study is declared passing the classic assumption test, as illustrated in the following table.

Table 4. Result of Normality Test

\begin{tabular}{|c|c|c|}
\hline \multicolumn{3}{|c|}{ One-Sample Kolmogorov-Smirnov Test } \\
\hline & \multicolumn{2}{|c|}{ Unstandardized Residual } \\
\hline $\mathrm{N}$ & & 477 \\
\hline \multirow{2}{*}{$\begin{array}{l}\text { Normal } \\
\text { Parameters }\end{array}$} & Mean & .0000000 \\
\hline & Std. Deviation & .24523829 \\
\hline \multirow{3}{*}{$\begin{array}{l}\text { Most } \\
\text { Extreme } \\
\text { Differences }\end{array}$} & Absolute & .038 \\
\hline & Positive & .038 \\
\hline & Negative & -.033 \\
\hline Test Statistic & & .038 \\
\hline $\begin{array}{l}\text { Asymp. Sig. } \\
\text { (2-tailed) }\end{array}$ & & $.115^{\mathrm{c}}$ \\
\hline \multicolumn{3}{|c|}{ a. Test distribution is Normal. } \\
\hline \multicolumn{3}{|c|}{ b. Calculated from data. } \\
\hline \multicolumn{3}{|c|}{ c. Lilliefors Significance Correction. } \\
\hline
\end{tabular}

Source: Primary Data Processed using SPSS25

Table 4 shows that the Asymp. Sig value was $0.115>0.05$. It concludes that the data examined were normally distributed.

Table 5. Result of Multicollinearity Test

\begin{tabular}{|c|l|l|l|}
\hline \multicolumn{4}{|c|}{ Coefficients $^{\mathbf{a}}$} \\
\cline { 3 - 4 } \multicolumn{2}{|c|}{ Model } & \multicolumn{2}{|c|}{ Collinearity Statistics } \\
\cline { 3 - 4 } \multicolumn{2}{|c|}{1} & Tolerance & VIF \\
\cline { 2 - 4 } & MobileMoneyUsage & .402 & 2.486 \\
\cline { 2 - 4 } & DigitalConsumerProtection & .402 & 2.486 \\
\hline \multicolumn{2}{|l|}{ a. Dependent Variable: Financial_Inclusion } \\
\hline
\end{tabular}

Source: Primary Data Processed using SPSS25 
DOI: $\underline{10.51386 / 25815946 / \mathrm{ijsms}-\mathrm{v} 4 \mathrm{i} 5 \mathrm{p} 116}$

Volume: 4 Issue: 5

September to October 2021

https://www.ijsmsjournal.org

Table 5 reveals that, based on the test above, the result of the tolerance value $>0.1$ and the value of VIF $<10$, indicating zero multicollinearity.

Table 6. Result of Heteroscedasticity Test

\begin{tabular}{|c|c|c|c|}
\hline \multicolumn{4}{|c|}{ Coefficients $^{\mathrm{a}}$} \\
\hline \multicolumn{2}{|c|}{ Model } & $\mathrm{t}$ & Sig. \\
\hline \multirow[t]{3}{*}{1} & (Constant) & 2.120 & .035 \\
\hline & MobileMoneyUsage & .079 & .937 \\
\hline & DigitalConsumerProtection & -.065 & .948 \\
\hline
\end{tabular}

Source: Primary Data Processed using SPSS25

In table 6 , it is discovered that the heteroscedasticity test obtained a significance value for the mobile money usage variable was 0.937 , while the significance value for the digital consumer protection was 0.948 . It shows that the independent variable significance value is over 0.05 , indicating zero heteroscedasticity.

The mediation analysis measured the effect of digital consumer protection as a mediating or intervening variable. This calculation was performed by applying linear regression, in which the results were adjusted to data processing using PROCESS. The mediation effect calculation results are displayed in the following table.

Table 7. Result of Effect Calculation using Linear Regression and PROCESS

\begin{tabular}{|l|c|c|c|c|c|c|c|c|c|}
\hline \multirow{2}{*}{ Predictor } & \multicolumn{3}{|c|}{ Digital Consumer Protection (M) } & \multicolumn{6}{c|}{ Financial Inclusion } \\
\cline { 2 - 10 } & \multicolumn{3}{|c|}{ Model 1 } & \multicolumn{2}{c|}{ Model 2 (Total Effect Model) } & \multicolumn{4}{c|}{ Model 3 } \\
\cline { 2 - 10 } & Coeff & SE & $\mathrm{p}$ & Coeff & SE & $\mathrm{p}$ & Coeff & SE & $\mathrm{p}$ \\
\hline Constant & 1.2973 & 0.1104 & 0.0000 & 1.4632 & 0.1343 & 0.0000 & 0.8810 & 0.1420 & 0.0000 \\
\hline $\begin{array}{l}\text { Mobile } \\
\text { Money Usage }\end{array}$ & 0.6950 & 0.0262 & 0.0000 & 0.6733 & 0.0318 & 0.0000 & 0.3614 & 0.0467 & 0.0000 \\
\hline $\begin{array}{l}\text { Digital } \\
\begin{array}{l}\text { Consumer } \\
\text { Protection }\end{array}\end{array}$ & & & & & & & 0.4487 & 0.0519 & 0.0000 \\
\hline
\end{tabular}

Source: Primary Data Processed using SPSS25

Details of the hypothesis model and calculation results are illustrated in Figure 3 as follows.

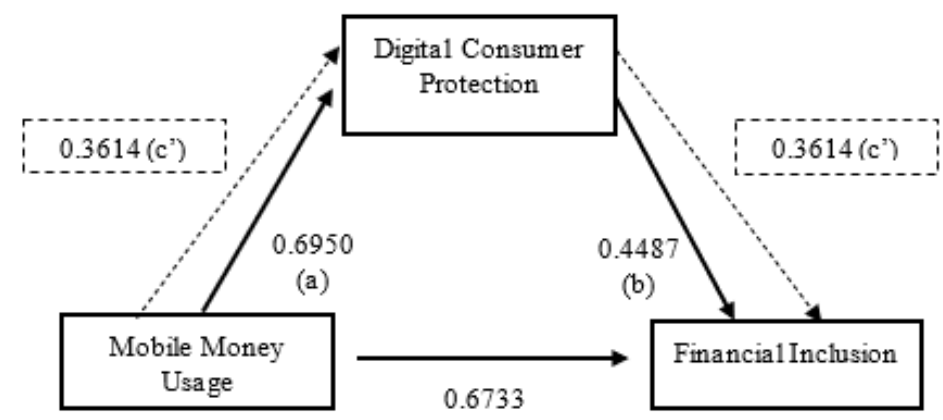

(c)

Fig 3. Hypothesis model and calculation results

Based on the Table 7 and Figure 3, it is concluded that the coefficient value of mobile money usage effect on financial inclusion in the second model observed in Table 7 was 0.6733 , with a significance or p-value $<0.05$. Meanwhile, the third model in Table 7 obtained a coefficient value of 0.3614 with a p-value $<0.05$. These results show that $\mathrm{H} 1$ of the study is accepted since mobile money usage significantly affected financial inclusion in the second and third models. Mobile money usage positively and significantly affected financial inclusion. That is, if the mobile money usage in the productive age group of Buleleng Regency increases, increased financial inclusion will occur. 
This result follows a predecessor study by Bongomin and Ntayi (2020), where mobile money usage had significant direct and indirect effects on financial inclusion ${ }^{[6]}$. A study by Bongomin et al. (2018) and advanced research by Bongomin and Ntayi (2019) also asserted the same finding, where mobile money usage significantly affected financial inclusion ${ }^{[7][8]}$. This statement and result reinforce another study finding by Jack and Suri (2014), revealing that mobile money usage could encourage access and utilization of financial services, particularly in rural communities ${ }^{[21]}$.

The coefficient value of mobile money usage effect on digital consumer protection was 0.6950 with a p-value $<0.05$. It shows that $\mathrm{H} 2$ in the study is accepted, where mobile money usage significantly affected digital consumer protection. Mobile money usage positively and significantly affected digital consumer protection, indicating that increased mobile money usage in the productive age group of Buleleng Regency will increase digital consumer protection. Increase mobile money usage will improve risks; thus, increased mobile money usage should be followed by increased consumer protection by the provider and regulator and improved knowledge of mobile money users.

The finding supports Caruana (2016), who examined extensive digital technology utilization, e.g., mobile money usage increased cyber-attack distribution and scale, triggering significant threats on user data safety and privacy in digital channels ${ }^{[12]}$. Therefore, consumer protection is required to improve user trust. The presence of a robust consumer protection program in digital financial services is vital in gaining trust and faith in consumers to reduce their doubt on the digital financial services regarding data safety problems and missed transactions ${ }^{[26]}$.

The coefficient value of digital consumer protection effect on financial inclusion was 0.4487 and the pvalue $<0.05$. The results show that $\mathrm{H} 3$ of the study is accepted since digital consumer protection significantly affected financial inclusion. It indicates that when digital consumer protection perceived by the productive age group of Buleleng Regency increases, financial inclusion will follow.

This finding follows the statement of OECD (2018), where a digital financial product and service environment that supports financial inclusion requires consumer protection more than ever ${ }^{[31]}$. Consumer protection is a vital element of an inclusive financial system, ensuring that the current formal financial service users receive transparent and fair treatment. It aims to foster trust in legal financial services and financial providers ${ }^{[15]}$. Based on data processing, the coefficient value between mobile money usage and financial inclusion in the second model was 0.6733 with a p-value $<0.05$, while the coefficient value in the third model was 0.3614 with a p-value $<0.05$. It shows that $\mathrm{H} 4$ in the study is accepted because the coefficient value in the second model is bigger than the third model, and there was a significant effect between mobile money usage on financial inclusion both in the second and third models. The subsequent analysis step was calculating the indirect effects via the mediating variable using the Sobel test. The step is illustrated in the following calculation.

$$
S a b=\sqrt{\left(0.4487^{2}\right)\left(0.0262^{2}\right)+\left(0.6950^{2}\right)\left(0.0519^{2}\right)+\left(0.0262^{2}\right)\left(0.0519^{2}\right)}
$$

$$
S a b=0,0380
$$

Furthermore, based on the above calculation, the t test result or also termed Sobel $\mathrm{Z}$ value is as follows:

$$
\begin{aligned}
& \mathrm{t}_{\text {test }}=\mathrm{Z}=\frac{a \times b}{S a b} \\
& \mathrm{t}_{\text {test }}=\mathrm{Z}=\frac{0.3119}{0.0380}=8.21
\end{aligned}
$$

Based on the 0.05 significance level, the $t_{\text {table }}$ was 1.96. The rule states that the Sobel $\mathrm{Z}$ value is significant if it is bigger than the effectiveness critical point of mediation effect, i.e., 1.96, for a 5\% significance level. Therefore, 
DOI: $\underline{10.51386 / 25815946 / \mathrm{ijsms}-\mathrm{v} 4 \mathrm{i} 5 \mathrm{p} 116}$

Volume: 4 Issue: 5

September to October 2021

https://www.ijsmsjournal.org

the $t_{\text {test }}$ or $\mathrm{Z}$ value was 8.21 , bigger than the $t_{\text {table }}$ or critical value of 1.96 . If $t_{\text {test }}>t_{\text {table }}$, it can be concluded that the mediation coefficient of 0.3119 is significant, indicating a mediating effect between mobile money usage, financial inclusion, and digital consumer protection variables, accepting $\mathrm{H} 4$.

The calculation was performed to observe the effect size and effect value of indirect effects via the mediating variable, obtaining an overall result in the Table 8.

Table 8. Results of Indirect-Direct Effect and Effect Size

\begin{tabular}{|l|l|l|l|l|}
\hline Indirect Effect & SE Indirect & Direct Effect & SE Direct & Effect Size \\
\hline 0.3119 & 0.0462 & 0.3614 & 0.0467 & 0.3226 \\
\hline
\end{tabular}

Source: Primary Data Processed using PROCESS by Hayes in SPSS25

According to the results in Table 8, it is concluded that the indirect effect of mobile money usage on financial inclusion via digital consumer protection mediator was 0.3119. Meanwhile, the direct effect of mobile money usage on financial inclusion was 0.3614 . The mediating variable value was observed from the effect size value, i.e., 0.3226 . Effect size values ranging from $0.15-0.35$ are categorized as moderate ${ }^{[14]}$. Thus, it concludes that the indirect effect was significant and moderate. This analysis result emphasizes that the digital consumer protection variable partially mediated mobile money usage effect on financial inclusion in the productive age group of Buleleng Regency, Bali. The study results reinforce a precedent study by Bongomin and Ntayi (2020), where the digital consumer protection variable also partially mediated mobile money usage effect on financial inclusion in Ugandan MSMEs ${ }^{[6]}$.

\section{CONCLUSIONS AND RECOMMENDATIONS}

Based on the study results and discussion, the conclusion is as follows:

1) Mobile money usage significantly affected financial inclusion. Therefore, the first hypothesis (H1) of the study is accepted. It indicates that increased mobile money usage increases financial inclusion from the financial transaction, service quality, and appropriate utilization aspects to support social welfare.

2) Mobile money usage significantly affected digital consumer protection, accepting the second hypothesis (H2) of the study. It shows that increased mobile money usage will strengthen digital consumer protection to protect users from cybercrime.

3) Digital consumer protection significantly affected financial inclusion. Thus, the third hypothesis (H3) of the study is accepted. It means that strong digital consumer protection will grow user trust in using financial services wiser and on target.

4) Digital consumer protection partially mediated mobile money usage effect on financial inclusion, accepting the fourth hypothesis (H4) of the study. It reveals that measures of financial inclusion improvement through mobile money usage should be supported by a robust digital consumer protection system from the regulation, legal, and technology ecosystem aspects.

The recommendation based on the results of this study is as follows:

1) The Financial Services Authority and Bank of Indonesia are expected to improve socialization and education for communities in the productive age group of Buleleng Regency regarding mobile money usage effect in improving financial inclusion and future wellbeing. Socialization and education on mobile money usage can be performed by cooperating with schools, higher educations, various communities, and business entities such as MSMEs that can be empowered by digital financial services.

2) The Indonesia Financial Services Authority, Bank of Indonesia, and the Ministry of Communication and Informatics should synergize in tightening the law concerning mobile money crime and fraud, reinforcing an efficient mechanism for help, compensation, and recovery to benefit cybercrime and cyber fraud victims located in the financial technology ecosystem. A strict law should be applied to parties committing cybercrime, particularly those related to mobile money usage, to guarantee user data safety.

3) Mobile money service providers should always innovate to create financial products or services required by the communities or users and ensure the mobile money system's reliability. They should 
DOI: $\underline{10.51386 / 25815946 / 1 j s m s-v 4 i 5 p 116}$

also ensure all entities in the mobile money ecosystem is protected and guaranteed for their safety, including personal data safety, stored balance/fund safety, transaction safety, and others.

4) The public is expected to have literacy or knowledge on finance and digital technology to find suitability between technology utilization and knowledge of the applicable technology. Better knowledge leads to better and target utilization. Moreover, the public should prioritize meticulous, cautious, and careful attitudes when using mobile money services.

\section{REFERENCES}

[1] Alliance for Financial Inclusion (AFI). (2020). Policy model on consumer protection for digital financial services. [online]. Available: https://www.afi-global.org/publications/3465/Policy-Model-on-Consumer-Protection-for-Digital-Financial-Services. [25 January $2021]$.

[2] Atkinson, A., \& Messy, F. (2013). Promoting Financial Inclusion through Financial Education. OECD/INFE Evidence, Policies and Practise", OECD Workng Papers on Finance, Insurance and Private Pensions, No. 34 OECD Publishing.

[3] Badan Pusat Statistik. (2020). Persentase Penduduk Miskin Provinsi Bali Menurut Kabupaten/Kota 2018-2020. [online]. Available: https://bali.bps.go.id/indicator/23/125/1/persentase-penduduk-miskin-provinsi-bali-menurut-kabupaten-kota.html. [26 January 2021].

[4] Badan Pusat Statistik. (2019). Persentase Penduduk Usia 5 Tahun ke Atas yang Mengakses Teknologi Informasi dan Komunikasi (TIK) dalam 3 Bulan Terakhir Menurut Kabupaten/Kota di Provinsi Bali, 2019. [online]. Available: https://bali.bps.go.id/statictable/2018/04/13/95/persentase-penduduk-usia-5-tahun-ke-atas-yang-mengakses-teknologi-informasi-dankomunikasi-tik-dalam-3-bulan-terakhir-menurut-kabupaten-kota-2019.html. [25 January 2021].

[5] Baron, R. M., \& Kenny, D. A. (1986). The Moderator-Mediator Variable Distinction in Social Psychological Research: Conceptual, Strategic, and Statistical.

[6] Bongomin, G. O. C., \& Ntayi, J. M. (2020). Mobile money adoption and usage and financial inclusion: mediating effect of digital consumer protection. Digital Policy, Regulation and Governance.

[7] Bongomin, G. O. C., Ntayi, J. M., Munene, J. C., \& Malinga, C. A. (2018). Mobile Money and Financial Inclusion in Sub-Saharan Africa: the Moderating Role of Social Networks. Journal of African Business, 19(3), 361-384. DOI: https://doi.org/10.1080/15228916.2017.1416214.

[8] Bongomin, G. O. C., \& Ntayi, J. (2019). Trust: mediator between mobile money adoption and usage and financial inclusion. Social Responsibility Journal.

[9] Bongomin, G. O. C., Ntayi, J. M., Munene, J. C., \& Nabeta, I. N. (2016). Social capital: mediator of financial literacy and financial inclusion in rural Uganda. Review of International Business and Strategy.

[10] BPMI Setpres. (2020). Presiden Jokowi Ingin Literasi dan Inklusi Keuangan Masyarakat Terus Ditingkatkan. [online]. Available: https://www.presidenri.go.id/siaran-pers/presiden-jokowi-ingin-literasi-dan-inklusi-keuangan-masyarakat-terus-ditingkatkan/. [2 October 2020].

[11] Camner, G. (2013). Implementing Mobile Money Interopability in Indonesia. [online]. Available: https://www.gsma.com/mobilefordevelopment/wp-content/uploads/2013/10/Implementing-mobile-money-interoperability-inIndonesia.pdf. [2 October 2020].

[12] Caruana, J. (2016). Financial inclusion and the fintech revolution: implications for supervision and oversight. In Conference Remarks at the Third GPFI-FSI Conference on Standard-Setting Bodies and Innovative Financial Inclusion "New frontiers in the supervision and oversight of digital financial services". (Vol. 26).

[13] CGAP-GPFI. (2010). Global Standard-Setting Bodies and Financial Inclusion for the Poor. [online]. Available at: http://www.gpfi.org/sites/default/files/documents/CGAP.pdf. [7 October 2020].

[14] Cohen, J. (1988). Statistical Power Analysis for the Behavioral Sciences (2nd ed.). Hillsdale N.J.: L. Erlbaum Associates.

[15] Consultative Group to Assist the Poor (CGAP). (2017). Digital credit focu s note (2017), For more information and recommendations for more responsible digital lending, based on consumer research and testing.

[16] Hasibuan, B. K., Lubis, Y. M., dan HR, W. A. (2018). Financial literacy and financial behavior as a measure of financial satisfaction. In 1st Economics and Business International Conference 2017 (EBIC 2017) (pp. 503-507). Atlantis Press. 


\section{DOI: $\underline{10.51386 / 25815946 / i j s m s-v 4 i 5 p 116}$}

Volume: 4 Issue: 5

September to October 2021

https://www.ijsmsjournal.org

[17] Hidayati, S. (2011). Cash-In and Cash-Out Agents for Mobile Money in Indonesia. Innovations: Technology, Governance, Globalization,6(4), 117-123. DOI: https://doi.org/10.1162/inov_a_00106.

[18] Indrawati. (2015). Metode Penelitian Manajemen dan Bisnis: Konvergensi Teknologi Komunikasi dan Informasi. Bandung: PT. Refika Aditama.

[19] Investing.com. (2020). Transaksi Uang Elektronik di Indonesia Melonjak 173\% di Januari 2020. [online]. Available: https://id.investing.com/news/economy/transaksi-uang-elektronik-di-indonesia-melonjak-173-di-januari-2020-1962884. [2 October 2020].

[20] Jack, W., \& Suri, T. (2011). Mobile money: The economics of M-PESA (No. w16721). National Bureau of Economic Research.

[21] Jack, W., \& Suri, T. (2014). Risk sharing and transactions costs: Evidence from Kenya's mobile money revolution. The American Economic Review, 104(1), 183-223. DOI: 10.1257/aer.104.1.183.

[22] Jayani, D. H. (2020). Transaksi E-Money Meningkat Saat PSBB. [online]. Available: https://databoks.katadata.co.id/datapublish/2020/09/11/transaksi-e-money-meningkat-saat-psbb. [2 October 2020].

[23] Joo, S., \& Grable, J.E., (2004). “An Exploratory Framework of the Determinants of Financial Satisfaction”. Journal of Family and Economic Issues, Vol. 25, No. 1,pp. 25-50.

[24] Juhri, K., \& Dewi, C. K. (2017). Kepercayaan dan Penerimaan Layanan Mobile Money T-Cash di Bandung dengan Pendekatan Technology Acceptance Model (TAM). Probisnis, 10(1).

[25] Kusuma, A.A.N.J., \& Indrajaya, I.G.B. (2020). Analisis Pengaruh Inklusi Keuangan Terhadap Tingkat Kemiskinan dan Ketimpangan Pendapatan Masyarakat di Kabupaten/Kota Provinsi. E-Jurnal Ekonomi Pembangunan Universitas Udayana, 9(5), 993-1022.

[26] Malady, L. (2016). Consumer protection issues for digital financial services in emerging markets. Banking \& Finance Law Review, Vol. 31 No. 2, pp. 389-401.

[27] Mbiti, I., \& Weil, D. N. (2011). Mobile banking: The impact of M-Pesa in Kenya (No. w17129). National Bureau of Economic Research, Massachusetts Avenue Cambridge, MA. [online]. Available: http://www.nber.org/papers/w17129.pdf. [1 Desember 2020]

[28] Moor, J. H. (1990), “The ethics of privacy protection”, Library Trends, Vol. 39 Nos 1/2, pp. 69-82.

[29] Moor, J. H. (1997), “Towards a theory of privacy I1”, Information Age: Computers and Society, Vol. 27 No. 3, pp. 27-32.

[30] Neolaka, A. (2014). Metode Penelitian dan Statistik. Bandung : PT Remaja Rosdakarya.

[31] OECD. (2018). G20/OECD Policy Guidance on Financial Consumer Protection Approaches in the Digital Age. [online]. Available: https://www.oecd.org/finance/G20-OECD-Policy-Guidance-Financial-Consumer-Protection-Digital-Age-2018.pdf. [25 January $2021]$.

[32] Otoritas Jasa Keuangan. (2019). Siaran Pers Survei OJK 2019 Indeks Literasi dan Inklusi Keuangan Meningkat. [online]. Available: https://www.ojk.go.id/id/berita-dan-kegiatan/siaran-pers/Pages/Siaran-Pers-Survei-OJK-2019-Indeks-Literasi-Dan-Inklusi-KeuanganMeningkat.aspx. [2 Oktober 2020].

[33] Otoritas Jasa Keuangan. (2016). Peraturan Otoritas Jasa Keuangan Nomor 76 Tahun 2016 Tentang Peningkatan Literasi keuangan dan Inklusi Keuangan di Sektor Jasa Bagi Konsumen dan/atau Masyarakat. [online]. Available: https://www.ojk.go.id/id/kanal/edukasi-dan-perlindungan-konsumen/regulasi/peraturan-ojk/Documents/Pages/POJK-tentangPeningkatan-Literasi-dan-Inklusi-Keuangan-di-Sektor-Jasa-Keuangan-Bagi-Konsumen-dan-atau-masyarakat/SAL\%20\%20POJK\%20Literasi\%20dan\%20Inklusi\%20Keuangan\%20-.pdf. [10 October 2020].

[34] Pertiwi, W. K. (2020). Penetrasi Internet di Indonesia Capai 64 Persen. [online]. Available: https://tekno.kompas.com/read/2020/02/20/14090017/penetrasi-internet-di-indonesia-capai-64-persen. [2 October 2020].

[35] Pratiwi, L. R. E., \& Krisnawati, A. (2020). Pengaruh Literasi Keuangan Terhadap Financial Self-Efficacy Pada Usia Produktif Di Kabupaten Buleleng, Bali. Jurnal Mitra Manajemen, 4(2), 171-183.

[36] Preacher, K. J., \& Hayes, A. F. (2004). SPSS and SAS Procedures for Estimating Indirect Effects in Simple Mediation Models. Behavior research methods, instruments, \& computers, 36(4), 717-731. 


\section{DOI: $\underline{10.51386 / 25815946 / \mathrm{ijsms}-\mathrm{v} 4 \mathrm{i} 5 \mathrm{p} 116}$}

Volume: 4 Issue: 5

[37] Putri, I. (2020). Selama Pandemi Cyber Crime Money Mule Meningkat di Indonesia. [online]. Available: https://inet.detik.com/security/d-5194351/selama-pandemi-cyber-crime-money-mule-meningkat-di-indonesia. [7 October 2020].

[38] Saji, T. G. (2019). Has demonetization made Indians to embrace digital technology in banking. International Journal of Science and Management Studies, 2(4), 19-25.

[39] Sekaran, U., \& Bougie, R. (2016). Research methods for business: A skill building approach. John Wiley \& Sons.

[40] Suhardi, D. A., \& Isfarudi, I. (2009). Efektivitas Variabel Mediator Berdasarkan Kontribusinya dalam Model Mediasi Sederhana. Jurnal Matematika Sains dan Teknologi, 10(1), 6-17.

[41] Sujarweni, W. (2015). Metodologi Penelitian Bisnis \& Ekonomi. Yogyakarta: Pustaka Baru Press.

[42] Ummah, B. B., Nuryartono, N., \& Anggraeni, L. (2015). Analisis inklusi keuangan dan pemerataan pendapatan di Indonesia. Jurnal Ekonomi dan Kebijakan Pembangunan, 4(1), 1-27.

[43] United Nations Capital Development Fund. (2020). Financial inclusion and the sdgs. [online]. Available: https://www.uncdf.org/financial-inclusion-and-the-sdgs. [1 Desember 2020].

[44] Upadhyay, P., \& Jahanyan, S. (2015). Analyzing user perspective on the factors affecting use intention of mobile based transfer payment. Internet Research, 26(1), 38-56. 2016. DOI:10.1108/IntR-05-2014-0143.

[45] Venkatesh, V., Morris, M., Davis, G., \& Davis, F. (2002). User acceptance of information technology: Toward a unified view. MIS Quarterly, 27(3), 425. DOI:10.2307/30036540.

[46] World Bank. (2012a). Good practices for financial consumer protection. [online]. Available: http://responsiblefinance.worldbank.org/publications/financial-consumer-protection. [2 October 2020].

[47] World Bank. (2012b). Information and Communications for Development: Maximizing Mobile, World Bank. Washington, DC. DOI: 10.1596/978-0-8213-8991-1. [online]. Available: www.worldbank.org/ict/IC4D2012. [2 October 2020].

[48] World Bank. (2012c). Malawi diagnostic review of consumer protection and financial literacy. Volume 1, Findings and Recommendations.

[49] Xiao, J. J. (2008). Applying behavior theories to financial behavior. In Handbook of consumer finance research (pp. 69-81). Springer, New York, NY. 